\title{
Polymorphism and genetic control of a plasma esterase in the eagle owl*
}

\author{
K. Radler
}

\author{
Department of Forest Genetics, University of \\ Göttingen, Büsgenweg 2, D-3400 Göttingen, \\ West Germany.
}

The genetic control of a plasma esterase polymorphism was investigated using starch gel electrophoresis of blood samples from 62 families of eagle owl (Bubo bubo). The segregation results suggest that this esterase type is inherited through one locus with two codominant alleles.

\section{INTRODUCTION}

Genetic markers observable by electrophoretic analyses are increasingly being applied in population genetics. They have become a general tool in studying genetic structures of populations and interactions between them.

A comparative review of enzyme polymorphisms in all taxa (Nevo, Beiles and Ben-Shlomo, 1984) showed that vertebrates tend to exhibit fewer polymorphic loci than either invertebrates or plants. Of the 1111 species investigated, 641 were vertebrate species, of which only 61 were birds. Although in recent years more has been published on this topic, even for birds, there is no study of enzyme polymorphism in the order Strigiformes.

In the course of investigations on the genetic aspects of conservation of endangered species, I am screening blood samples of several hundred eagle owls (Bubo bubo) for enzyme polymorphisms. The first enzyme found to be polymorphic was an esterase active in the blood plasma.

The genetic interpretation of electrophoretic patterns can be deduced to some degree from the variability in zymograms observed, the quaternary structure and population data (Allendorf and Utter, 1979). However, it is becoming commonly appreciated that ultimate proof and verification of

\footnotetext{
* Dedicated to Freiherr $O$. von Frankenberg und Ludwigsdorf-founder and leader of the "Aktion zur Wiedereinbürgerung des Uhus (AZWU)" (Initiative for Reintroduction of the Eagle Owl)-on his 70th birthday.
}

the mode of inheritance is deducible solely from controlled crossings or complete family data (Stahl and Ryman, 1982). This type of data will be presented in this paper to clarify the genetic control of this enzyme polymorphism. The genetics of esterases have been studied in a wide range of species. Most results suggested that the enzyme was monomeric, and was genetically controlled by one locus with codominant alleles.

\section{MATERIAL AND METHODS}

Blood samples were collected from the stock population of a private initiative concerned with the reintroduction of the eagle owl into northwestern Germany (Frankenberg et al., 1983). This organisation is supported by about 100 zoos and private conservationists all over Central Europe. All of these supporting members gave up their eagle owl fledglings, which were propagated in captivity, for release into the wild.

About $5 \mathrm{ml}$ of blood was taken from each bird of breeding pairs and their offspring during the years 1983 and 1984. This was done according to common veterinary practice. Blood was prevented from coagulating by adding a solution of sodiumcitrate and -chlorite. The blood samples were sent by express mail to the laboratory in a specially designed cooling box. After separation of plasma and cells, these samples were stored at $-40^{\circ} \mathrm{C}$ until electrophoretic analysis was performed.

Electrophoretic separation was performed by means of starch gel zone electrophoresis using 12 
Table 1 Segregation results of a plasma esterase polymorphism in the eagle owl. Phenotypes see figure 1

\begin{tabular}{|c|c|c|c|c|c|c|c|}
\hline \multirow{2}{*}{$\begin{array}{l}\text { Mating types } \\
\text { Phenotype } \\
\$ \times \delta\end{array}$} & \multirow[b]{2}{*}{$\begin{array}{l}\text { No of } \\
\text { pairs }\end{array}$} & \multicolumn{4}{|c|}{ Offspring (expected number in brackets) } & \multirow{2}{*}{\multicolumn{2}{|c|}{$\chi^{2}(\alpha=0.05)$}} \\
\hline & & Total & $\mathrm{FF}$ & $\begin{array}{l}\text { Phenotypes } \\
\text { SS }\end{array}$ & FS & & \\
\hline $\mathrm{SS} \times \mathrm{FF}$ & 1 & 3 & - & - & $3(3 \cdot 0)$ & & \\
\hline $\mathrm{SS} \times \mathrm{SS}$ & 33 & 118 & - & $118(118 \cdot 0)$ & - & & \\
\hline $\mathrm{SS} \times \mathrm{FS}$ & 14 & 49 & - & $28(24 \cdot 5)$ & $21(24 \cdot 5)$ & $1 \cdot 00$ & N.S. \\
\hline $\mathrm{FS} \times \mathrm{SS}$ & 8 & 27 & - & $13(13 \cdot 5)$ & $14(13 \cdot 5)$ & 0.04 & N.S. \\
\hline \multirow[t]{2}{*}{$\mathrm{FS} \times \mathrm{FS}$} & 6 & 21 & $4(5 \cdot 25)$ & $9(5 \cdot 25)$ & $8(10 \cdot 5)$ & $4 \cdot 04$ & N.S. \\
\hline & 62 & 218 & 4 & 168 & 46 & & \\
\hline
\end{tabular}

per cent starch and the buffer system of Poulik (1957) as modified by Bergmann (1973). The staining mixture was modified from Brewer (1970): $8 \mathrm{ml}$ of $\alpha$ - and $4 \mathrm{ml}$ of $\beta$-naphtyl acetate ( 1 per cent solution), $50 \mathrm{mg}$ Blue RR salt per $100 \mathrm{ml}$ solution of tris- $\mathrm{HCl}, \mathrm{pH} 6 \cdot 0$.

\section{RESULTS AND DISCUSSION}

Five different isozyme mobility levels were observed in the investigated population. They were designated according to their relative mobilities, meaning percentages relative to the fastest moving type (fig. 1). While the bands 90 and 70 were visible very rarely and only in samples with great overall staining activity, the band 30 always appeared. Only the bands at levels 100 and 95 appeared with individual variation. The three possible types are shown in fig. 1. These types are assumed to be under the genetic control of one gene locus. In testing this hypothesis, the segregation ratios of 62 complete families were considered, i.e., the

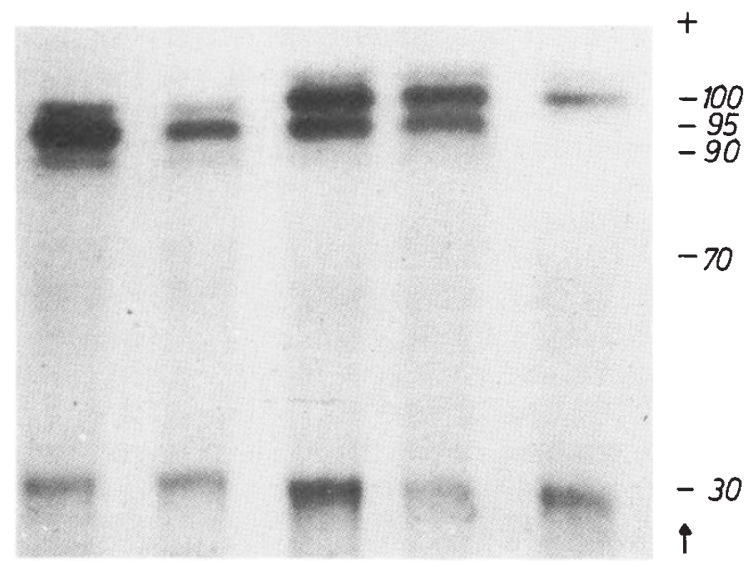

Figure 1 Zymographic phenotypes of plasma esterase in eagle owl. Genotypes controlling mobility levels 100 and 95 are SS, SS, FS, FS, FF (from left to right). For details see text. enzyme-phenotypes of both parents as well as of the entire clutch of the breeding years of 1983 and 1984. These results are given in table 1 . In species with a low yearly fecundity rate, it is statistically not feasible to test segregation ratios for individual families. Therefore, all offspring of mating pairs with similar phenotypes have been pooled for these estimates. The congruency of these observed segregation ratios with those expected is a necessary, but not necessarily sufficient, condition for this congruency in each single family.

As table 1 shows, the observed phenotypic distributions among the offspring are consistent with the expected ratios when only one of the parents is heterozygous. Similarly, there is no significant deviation among those of double heterozygous parents. From these results, I have no reason to reject the assumed inheritance mode of one locus with two codominant alleles. The observed deviations might indicate a slight selective advantage in viability of offspring carrying the $\mathrm{S}$ gene; i.e., the phenotypes SS and FS. The blood samples were available only when the progeny were 6 to 10 weeks of age. An estimate of varying survival rates during this period is very difficult to achieve, but data are being accumulated to assess the feasibility of this assumption.

Acknowledgment I am much obliged to all those who allowed access to their aviaries and to W. Bergerhausen for taking blood samples. This work was supported by a grant of the Niedersächsisches Ministerium für Wissenschaft und Kunst.

\section{REFERENCES}

AllendorF, F. W. AND UTTER, F. M. 1979. Population Genetics. In Fish Physiology 8, Hoar W. S. et al. (eds), Acad. Press, New York, p. 407-454.

BergmanN, F. 1973. Genetische Untersuchungen bei Picea abies mit Hilfe der Isoenzym-Identifizierung. Theoret. and Appl. Genetics, 43, 222-225.

BREWER, G. J. 1970. Introduction to isozyme techniques. Academic Press, London. 
FRANKENBERG, O. VON, HERRLINGER, E. AND BERGERHAUSEN, W. 1983. Reintroduction of the European eagle owl (bubo b. bubo) in the Federal Republic of Germany. International Zoo Yearbook, 23, 95-100.

NEvo, E., BEILES, A. AND BEN-SHLOMO, R. 1984. The evolutionary significance of genetic diversity: ecological, demographic and life history correlates in Mani, G. S. (ed.)
Evolutionary dynamics of Genetic diversity, pp. 13-213. Springer-Verlag, Berlin. (Lecture Notes in Biomathematics, 53).

POULIK, M. D. 1957. Starch gel electrophoresis in a discontinuous system of buffers. Nature, 1980, 1477-79.

STAHL, G. AND RYMAN, N. 1982. Simple Mendelian inheritance in locus coding for a-glycerophosphate dehydrogenase in brown trout (Salmo trutta). Hereditas, 96, 313-315. 